\title{
Empirical Approach for the US Companies in Dual Perspectives: Effective Tax Rates and the Remuneration of CEO
}

\author{
Georgeta Vintilă and Radu Alin Păunescu \\ Department of Finance, Bucharest University of Economic Studies, Bucharest, Romania \\ Correspondence should be addressed to: Radu Alin Păunescu; radupaunescu696@gmail.com
}

Received date: 26 October 2015; Accepted date: 11 December 2015; Published date: 28 December 2015

Academic Editor: Aura Emanuela Domil

Copyright (C) 2015. Georgeta Vintilă and Radu Alin Păunescu. Distributed under Creative Commons CC-BY 4.0

\begin{abstract}
We tried a dual perspective to analyse companies from technology sector, listed on NASDAQ stock exchange market and components of Dow Jones in 2007-2013. The approach focused on the effective corporate tax rate but we included elements of corporate goverance such as CEO remuneration. Thus, we observed the relation of managers-shareholders-investors in the context of corporate we use least squares method (OLS) and the method of generalized least squares (GLS) with fixed-effects models applied for data panels. We also used the method of White for heteroskedasticity. The main models have highlighted the determinants of EITR (effective tax rate). The results are interesting and it should be noted that they align with the results given by previous studies. We obtained a mixed correlation between influencing factors based on financial statements and also based on CEO remuneration (Salary, Bonus, Stock_Award).
\end{abstract}

Keywords: effective tax rate; corporate finance. As estimation models finance; fiscal management

JEL Classification: G30; H21; H25; H26

\section{Introduction}

Many voices in the economic and financial world keep asking themselves whether the presence of the last crisis from 2007 is haunting in our global financial system and if is waiting for a more powerful return. Whatever the answer to this question, they should be aware that prosperity in terms of economic growth, social development and better living standards depends on key factors including effective fiscal management within companies.
The paper addresses a topical issue with purpose of highlighting the factors that influence the effective tax rate of companies listed on US exchanges. The research focuses on effective corporate tax rate, because it captures the essence of many decisions taken by the management of a company and to support that subject we included elements of CEO remuneration. Fiscal management is a matter of interest to managers of companies that directly affects policies and investment strategies. And so it becomes a matter for the shareholders. At the base of the fiscal management is the efficient and optimal

Cite this Article as: Georgeta Vintilă and Radu Alin Păunescu (2015), "Empirical Approach for the US Companies in Dual Perspectives: Effective Tax Rates and the Remuneration of CEO", Journal of Financial Studies \& Research, Vol. 2015 (2015), Article ID 493082, DOI: 10.5171/2015.493082 
manner of doing business taking into consideration the tax liabilities. A proper fiscal management fulfills the objectives proposed in tax planning, but this is one of the responsibilities of the company manager, so it is interesting to follow the link between CEO remuneration and the effective tax rate, as a final result of fiscal management. Its role is to optimize the fiscal cost by restructuring the fiscal result, having as an ultimate goal, a lower cost, to the extent permitted by law. To achieve an effective reduction in the cost of tax, managers have to use tax deductions granted by the State, and the result of this will be reflected in the remuneration received. Methodology for establishing effective corporate tax level is important because some taxes can have a negative impact on economic growth and social welfare. It is therefore important to capture elements of human nature specific to managers and the forms of remuneration (salary, bonus, stock award) are a first step in the analysis of interference of taxation and corporate governance. Another point of interest is the fact that the effective tax rate has a considerable effect on the profitability of a company and on cash flow.

The novelty of the paper consists in explaining the role of effective corporate tax rate with accents set on corporate finance perspective and CEO remuneration. The scope is to adopt an approach based less on fiscal management but more on understanding the factor within corporate finance which are acting as influence factors on effective tax rate. To support these objectives, we provide an empirical research study for 50 companies common to Dow Jones and NASDAQ. Another role of the paper is to provide a picture of the US tax management after the financial crisis in 2007.

The rest of the paper is organized as follows. Section 2 includes research and conclusions of literature recognized in finance; Section 3 includes the hypotheses proposed; Section 4 includes description of database, the methodology used for empirical research and the results. The final section includes conclusions and provides some suggestions for future research directions that will bring a contribution to the results obtained in the present paper.

\section{Prior Research in the Scientific Literature}

The effective tax rate calculation follows two main trends. First, the classic one is based on financial reports and assumes the ratio of tax liabilities and current profit. In this regard, it can be mentioned Buijink and Janssen (2000) that analyze companies in the European Union. Nicodème (2007a) introduced in the analysis the United States and Japan. The second trend is based on the theory of investment and underlines the link between cost of capital and effective average tax rate. It was developed by Devereux and Griffith in 1999 and shows the burden of taxation on investment projects. Djankov et al. (2010) proposed another model preferred with social security benefits.

There is a strong connection between financial performance and effective tax rates. Every study about tax rates included in their empirical research a link with return on assets (ROA), return on equity (ROE) and other performance indicators. Very common is ROA. Gupta and Newberry (1997) consider that a ROA increase will lead to an increase in EITR. Phillips (2003), Lee and Swenson (2012) achieved a positive correlation. Richardson and Lanis (2007) recorded a positive correlation between ROA and EITR, but with the effect of tax reforms, the correlation became negative. Md Noor et al (2010) obtained a negative correlation between ROA and EITR. Gropp (1997) considers that if companies have a tax system with higher income, taxes tend to increase leverage. An increasing leverage connotes a higher rate of indebtedness with reduction effect of corporate income taxes. In literature there are two divided opinions on the influence of company size on EITR. Nicodeme (2007b) considers that large companies have a greater political power and thus, they may impose a reduction of EITR in their own interest. Md Noor et al. (2010) obtained by empirical ways the political cost presence and noted that larger firms were paying higher effective tax rates because of it. Political power is also supported by studies of Hsieh (2012), Richardson and Lanis (2007). The second debate about firm size is around the idea of "political cost". Zimmerman (1983) considers that a larger company is more taxed by the state and the net income becomes smaller, followed by an increase of EITR. Kern and Morris (1992) considered that company size determines a greater difference 
between what is recorded in accounting and what is reported to be taxable, because through their size, companies are not afraid of penalties.

The shareholders of a company appreciate managers who have the ability to reduce the effective tax rate and reward them according to the level of tax burden reduction (Bauman and Schadewald, 2001). According to corporate governance, the new corporate governance code issued to the US in 2013 (see in Appendix) is comprised of the provision according to which the managers remuneration should be paid depending on a package of financial performance indicators which reflect the long-term strategy. Another principle which is added to this idea is the one that says that through remuneration it should be noted if there is new value in company. Haldane (2011) recalls the concept of "myopia loop" materialized through decisions of managers of US banks which lacked long-term positive effects. For the granting of remuneration, the main element was focused on ROE indicator that can be manipulated in financial terms - accounting. Haldane said that by 2007, the CEO remunerations of the largest US banks had become 500 times bigger. The spectacular growth was not due to the corporate governance but due to the lack of importance accorded to it. US Corporate Governance Code published in 2012 requires that managers be paid in accordance with the performance achieved by the company without exceeding more than 1 million dollars, and in that way being efficient from a tax perspective. CEO's remuneration in the context of effective corporate tax rate was studied by Phillips (2003), which analyzed the effectiveness of tax planning on it. Empirical evidence obtained by Phillips (2003) shows that if business unit manager is rewarded depending on financial performance after tax, through the effective tax rate management, it reduces it. The results do not support a link between CEO's remuneration, according to the recorded performance after applying the statutory tax rate, and the effective tax rate reduction, but in that they establish the business-unit manager remuneration, they have an indirect role in this reduction. However, it does not mean that the CEO is not concerned with the results after applying taxation. By the nature of the job they are dealing with the company, they have to achieve this task.

\section{Hypotheses Development}

The main aim of the present work is to identify quantitative approaches of effective tax rate for NASDAQ listed companies in the technology sector. Based on the models found in the literature, we have established the following empirical research hypotheses:

- Hypothesis $1\left(\mathrm{H}_{1}\right)$ : The existence of a positive correlation between the effective corporate tax rate and ROA (Gupta and Newberry, 1997; Lee and Swenson, 2012 )

- Hypothesis $2\left(\mathrm{H}_{2}\right)$ : The existence of a negative correlation between indebtedness and the effective corporate tax rate (Vintilă et al, 2012; Richarson and Lanis, 2007)

- Hypothesis $3\left(\mathrm{H}_{3}\right)$ : The existence of a positive correlation between capital intensity and the effective corporate tax rate (Buijnik and Janssen, 2000)

- Hypothesis $4\left(\mathrm{H}_{4}\right)$ : The existence of a negative correlation between company size and the effective corporate tax rate (Kim and Limpaphayom, 1998; Nicodème, 2007b)

- Hypothesis $6\left(\mathrm{H}_{6}\right)$ : The existence of a positive correlation between the company's financial leverage and the effective corporate tax rate (Vintilă and Păunescu, 2014)

- Hypothesis $7\left(\mathrm{H}_{7}\right)$ : The existence of a negative correlation between different CEO Remunerations (Salary, Bonuses, Stock Awards) and the effective corporate tax rate

- Hypothesis $8\left(\mathrm{H}_{8}\right)$ : The existence of a positive correlation between Growth as assets variation over years and the effective tax rate

\section{Database and variables used}

The purpose of this paper is the approaching of the effective tax rate in a quantitative way using econometric methodology. Our aim is to empirically investigate the endogenous influence factors of effective tax rate from corporate finance. Even more, we want to identify a link between these factors and we want to add more factors from the system of remuneration / compensation of the CEO, thus making a brief transition of effective tax 
rate in the corporate governance mechanism. The period covers the period 2007-2013, after the crisis in 2007, when most companies have encountered financial performance struggles and, hence, the effective tax rate was affected likewise. There were analyzed a total of 50 companies predominant components of the Dow Jones index and some of them listed on NASDAQ stock exchange. It should be noted that companies from financial area such as Goldman Sachs, JP Morgan and Visa were excluded. Data were retrieved and processed from accounting documents provided by Thomson Reuters Eikon database. Except the accounting documents, the database also includes information necessary for carrying out the corporate governance variables. Among the variables included are those linked with debt, those related to the structure of assets and capital but also new elements such as CEO remuneration.

Table 1 describes the variables used in econometric models of this empirical research.

Table 1: Description of the variables

\begin{tabular}{|c|c|c|}
\hline \multirow[b]{2}{*}{$\begin{array}{l}\text { Dependent } \\
\text { Variable }\end{array}$} & Variables & Description * \\
\hline & EITR $_{\text {it }}$ & Income Tax (Total) / Net income Before Taxes (EBIT) \\
\hline $\begin{array}{l}\text { Independent } \\
\text { Variables }\end{array}$ & $\mathrm{ROA}_{\text {it }}$ & $\begin{array}{l}\text { Net income/ Total Assets } \\
\text { Return on Assets, ROA, measures the efficiency of capital allocation in } \\
\text { fixed assets and net current assets. }\end{array}$ \\
\hline \multirow{5}{*}{$\begin{array}{l}\text { Independent } \\
\text { Variables } \\
\text { Constant }\end{array}$} & SIZE $_{\text {it }}$ & $\begin{array}{l}\text { Ln (Total Assets) } \\
\text { It shows the firm size }\end{array}$ \\
\hline & STRAST $_{\text {it }}$ & $\begin{array}{l}\text { Property, Plant, Equipment, Total Net / Total Assets } \\
\text { Named in academic literature as capital intensity }\end{array}$ \\
\hline & DEBT $_{\text {it }}$ & $\begin{array}{l}\text { Total Liabilities / Total Assets } \\
\text { L/A ratio is a solvency ratio that examines how much of a company's } \\
\text { assets are made of liabilities. }\end{array}$ \\
\hline & $\mathrm{GROWTH}_{\text {it }}$ & [(Total Assets2001 - Total Assets2000)/Total Assets2000] \\
\hline & $\mathrm{LEV}_{\text {it }}$ & $\begin{array}{l}\text { Total Debt / Total Equity } \\
\text { Financial leverage indicates what proportion of debt and equity is used } \\
\text { by the company to finance its assets }\end{array}$ \\
\hline \multicolumn{3}{|r|}{ CEO Remuneration } \\
\hline \multirow{3}{*}{$\begin{array}{l}\text { Independent } \\
\text { Variables }\end{array}$} & SALARY $_{\text {it }}$ & Ln(Basic Salary - Salary without compensations) \\
\hline & BONUS $_{\text {it }}$ & Ln(Bonus Salary - Bonuses and compensations) \\
\hline & STOCK_A $A_{\text {it }}$ & Ln(Compensations in Stocks awards) \\
\hline
\end{tabular}

Effective corporate tax rate can be calculated in various ways and using several formulas, proposed by Gupta and Newberry (1997), Nicodeme (2007a) and others.

\section{Econometric research methodology}

For empirical research methodology, we used data panel models with multivariate analysis of influence factors for the effective tax rate.
The theoretical forms for econometric model used for analyzing the impact of various factors on EITR in period 2007-2013 are:

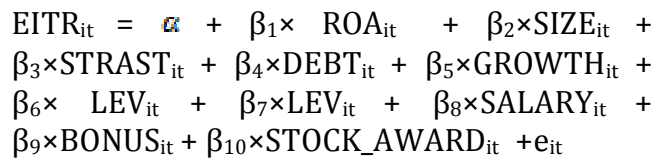


OLS estimation assumes that all observations have the same variance of errors and that errors are independent. Panel models do not comply with these rules, so, to eliminate heteroskedasticity, multicollinearity, autocorrelation errors which are affecting the estimations we used generalized least squares (GLS), standard error correction for heteroskedasticity using White's method, and fixed effects (FE). All these methods are designed to produce Best Linear Unbiased Estimators (BLUE) which give the true values for parameters. Gujarati (2003) considers that GLS estimation can eliminate heteroscedasticity from data and FE allow better OLS estimates. Brooks (2008) believes that fixed effects are a plausible choice when selected companies belong to the same population, such as a stock index. The 50 companies selected are components of the Dow Jones and listed on NASDAQ, and thus we can consider that fixed effects are more suitable for econometric modeling. Al-Najjar (2014) considers that the panel data are not the most suitable for the econometric analysis because the corporate governance factors do not change considerably during the time. But we consider that the CEO remunerations are proto-variables for corporate governance and are quite different from the characteristics of board members and CEO. Coles et al. (2005) warn that in the econometric estimation of the relationships between the corporate governance and the financial performance of the companies there can appear the endogeneity problem.

\section{Descriptive Statistics}

In Table 2 we attached the results of Descriptive Statistics.

Table 2: Descriptive statistics

\begin{tabular}{|c|c|c|c|c|c|c|c|}
\hline Variables & Max & Min & Mean & Std. Dev. & Skewness & Kurtosis & Obs \\
\hline EITR & 0.72 & 0 & 0.27 & 0.11 & -0.38 & 3.66 & 350 \\
\hline ROA & 0.38 & -0.34 & 0.12 & 0.09 & 0.06 & 5.28 & 350 \\
\hline SIZE & 20.5 & 4.47 & 15.25 & 4.23 & -1.1 & 3.1 & 350 \\
\hline STRAST & 1.17 & 0 & 0.25 & 0.21 & 1.67 & 6.6 & 350 \\
\hline DEBT & 12.83 & 0.02 & 0.58 & 1.32 & 7 & 54.25 & 350 \\
\hline GROWTH & 15.46 & -0.38 & 0.14 & 0.84 & 17.53 & 320.63 & 350 \\
\hline LEV & 8.02 & -5.81 & 0.68 & 1.3 & 2.49 & 13.48 & 350 \\
\hline SALARY & 20.05 & 0 & 7.50 & 2.06 & -3.94 & 28.7 & 350 \\
\hline BONUS & 15.83 & 0 & 13.66 & 7.03 & -0.09 & 1.08 & 350 \\
\hline STOCK_A & 17.36 & 0 & 8.25 & 7.43 & -0.18 & 1.09 & 350 \\
\hline
\end{tabular}

Source: Author's computations in Eviews 9

From Table 2, it can be seen that the mean for EITR is $27 \%$ (official level for statutory rate in that period was around 39\% according to Tax Foundation) and one can deduce that in the context of after-crisis period, big companies from US stock exchange managed to use tax deduction and tax breaks to reduce their effective corporate tax rates. The gap between effective and statutory rates can be a signal of the presence of tax aggressiveness. But in the same time, some companies had huge level of tax - $72 \%$ for ASTE (stock symbol) or they registered losses. Number of observations is 350 .

\section{Empiric Results}

In our econometric estimations we used balanced data panel. For fixed effects (FE) we applied the Redundant Fixed Effects Tests which support the use of these effects because the $P$-value associated with the test is less than $5 \%$ as can be seen in Table 3 
Table 3: Redundant Fixed Effects Tests

\begin{tabular}{|l|c|c|c|}
\hline \multicolumn{4}{|l|}{ Redundant Fixed Effects Tests } \\
\hline Test cross-section fixed effects \\
\hline Effects Test & Statistic & d.f. & Prob. \\
\hline Cross-section F & 7.393068 & $(49,291)$ & 0.0000 \\
\hline Cross-section Chi-square & 283.028367 & 49 & 0.0000 \\
\hline
\end{tabular}

Source: Author's computations in Eviews 9

In Table 4 there are the estimation results for all three estimation methods.

Table 4: Estimation Results

\begin{tabular}{|c|c|c|c|c|c|c|}
\hline & \multicolumn{2}{|c|}{ ROA } & \multicolumn{2}{|c|}{ ROA GLS } & \multicolumn{2}{|c|}{ ROA GLS FE WHITE } \\
\hline & $\beta$ & Std. Err. & $\beta$ & Std. Err. & $\beta$ & Std. Err. \\
\hline ROA & $\begin{array}{l}0.137 \\
(2.11) \\
\end{array}$ & 0.065 & $\begin{array}{r}0.108 \\
(3.02) \\
\end{array}$ & 0.036 & $\begin{array}{r}0.163 \\
(4.10) \\
\end{array}$ & 0.040 \\
\hline SIZE & -0.001 & 0.001 & $\begin{array}{l}-0.003 \\
(-3.23) \\
\end{array}$ & 0.001 & $\begin{array}{l}-0.017 \\
(-4.30) \\
\end{array}$ & 0.004 \\
\hline STRAST & $\begin{array}{l}0.203 \\
(8.11) \\
\end{array}$ & 0.025 & $\begin{array}{c}0.193 \\
(17.74) \\
\end{array}$ & 0.011 & 0.028 & 0.028 \\
\hline DEBT & $\begin{array}{l}0.011 \\
(2.15) \\
\end{array}$ & 0.005 & $\begin{array}{c}0.01 \\
(3.78) \\
\end{array}$ & 0.003 & $\begin{array}{l}-0.016 \\
(-1.73) \\
\end{array}$ & 0.009 \\
\hline GROWTH & $\begin{array}{r}0.011 \\
(1.88) \\
\end{array}$ & 0.006 & $\begin{array}{r}0.011 \\
(2.23) \\
\end{array}$ & 0.005 & $\begin{array}{r}0.012 \\
(3.13) \\
\end{array}$ & 0.004 \\
\hline LEV & -0.008 & 0.005 & $\begin{array}{l}-0.006 \\
(-2.16) \\
\end{array}$ & 0.003 & 0.004 & 0.003 \\
\hline SALARY & 0.003 & 0.003 & 0.001 & 0.002 & $\begin{array}{l}-0.005 \\
(-3.83) \\
\end{array}$ & 0.001 \\
\hline BONUS & $\begin{array}{l}0.002 \\
(2.82) \\
\end{array}$ & 0.001 & $\begin{array}{r}0.002 \\
(3.78) \\
\end{array}$ & 0.000 & 0.000 & 0.000 \\
\hline STOCK_A & -0.000 & 0.001 & 0.000 & 0.000 & 0.000 & 0.001 \\
\hline $\mathrm{C}$ & $\begin{array}{l}0.161 \\
(4.48) \\
\end{array}$ & 0.036 & $\begin{array}{l}0.237 \\
(7.38) \\
\end{array}$ & 0.032 & $\begin{array}{c}0.583 \\
(9.00) \\
\end{array}$ & 0.065 \\
\hline R-squared & \multicolumn{2}{|c|}{0.230} & \multicolumn{2}{|c|}{0.533} & \multicolumn{2}{|c|}{0.887} \\
\hline Adjusted R ${ }^{2}$ & \multicolumn{2}{|c|}{0.210} & \multicolumn{2}{|c|}{0.520} & \multicolumn{2}{|c|}{0.865} \\
\hline F-statistic & \multicolumn{2}{|c|}{11.313} & \multicolumn{2}{|c|}{43.090} & \multicolumn{2}{|c|}{39.601} \\
\hline
\end{tabular}

Source: Author's computations in Eviews 9. Notes: Only statistically significant variables ${ }^{*}$ Significant at the 5percent level) are bolded and in brackets are included the T- Student values. Std. Err depicts the Standard Error of the Regression. Description of the variables is provided in Table 1.

Besides the statistical inference, the first step to ensure the validity of estimated results obtained is to analyze the dispersion. Confidence level associated to coefficients is given by their standard error (Std. Error). If Std. Err. values are lower than coefficients values, we can assume that the estimators are relevant with a high degree of confidence. From Table 4 it is observed that the results comply with this hypothesis for all estimation methods. Bourbonnais and Andrei (2008) recommend that the lower limit of determination ratio $\mathrm{R}^{2}$ (goodness of fit statistic) to be 0.15 , and that limit was exceeded in all estimation methods. The $\mathrm{F}$ test probability was null for all methods of estimation and we accepted the validity of the models for a confidence level of $95 \%$. The 
consequences of ignoring the autocorrelation are similar to those of ignoring the heteroskedasticity. The coefficients estimated by OLS method are unbiased but are not BLUE and are therefore ineffective. GLS estimation is a method which can rectify that problem. One can see that by using more correction methods of estimation (FE, GLS, White), $\mathrm{R}^{2}$ reached a value of $88 \%$ from $23 \%$, a fact which gives it more validity and robustness to the model by removing the disturbance phenomena. More, reasoning for using these methods of estimation consists in the idea of similar robust results obtained through as many methods of estimation. If an independent variable has positive or negative significance in all estimation methods, we can assume with certainty that the variable has the same signification / influence on the effective tax rate.

From an economical point of view, the influence sign of significant independent variables on EITR is important so it can be seen in Table 5.

Table 5: The significance of influence of independent variables on EITR

\begin{tabular}{|c|c|c|c|}
\hline & ROA & ROA GLS & ROA GLS FE WHITE \\
\hline ROA & + & + & + \\
\hline SIZE & & - & - \\
\hline STRAST & + & + & - \\
\hline DEBT & + & + & + \\
\hline GROWTH & + & + & - \\
\hline LEV & & - & \\
\hline SALARY & & & + \\
\hline BONUS & + & + & + \\
\hline STOCK_A & & + & \\
\hline C & + & & \\
\hline
\end{tabular}

Source: Author's computations

Significant negative influence on the effective tax rate is recorded for variables SIZE, DEBT, LEV, and SALARY. Positive influence on EITR was obtained for variables ROA, STRAST, DEBT, GROWTH and BONUS.

Return on assets (ROA) sometimes named "managers' profitability", is the indicator of financial performance and is suitable in the context of CEO remuneration because it measures the efficiency of capital allocation in fixed assets and shows the ability of CEO to manage. We checked the proposed $\mathrm{H}_{1}$ hypothesis. The results obtained are supported by the work of Gupta and Newberry (1997). This can be attributed to a situation in which the company sold redundant or old assets, resulting in an increase in ROA, but having difficulties to work at the same level as before sale, and thus, recorded a smaller net income before taxes. Still, an increase in financial performance should be reflected as an improvement on all levels within a company. The company size (SIZE) has a reducing influence on effective tax rate. We checked the hypothesis $\mathrm{H}_{4}$ regarding negative correlation between company size and effective tax rate. The results obtained are supported by the work of Nicodème (2007b). These include the presence of so-called "political cost". All of the 50 analyzed companies are among the largest or even the largest from the US and from the world, and thus, it can explain the result obtained. A large company owns the financial strength which enables the adoption of new technologies both on the operational level and the financial reporting system for enabling earnings management and tax optimization. The variable (DEBT) is a global leverage ratio which can show the financial risk of a company. We capture a mixed signification for this variable. From an economic point of view, the negative one is based on the tax savings and tax deductions resulting from the interest expenses which reduce the EITR. The same significance was obtained by Richardson and Lanis (2007), Vintilă and Păunescu (2014). The positive 
signification can be explained by the fact that a higher indebtedness entails a greater risk which requires non-deductible costs with growing influence on EITR and may become a negative psychological factor for the CEO and his managerial abilities. Capital intensity is important as investment in fixed assets involves interest expenses and tax depreciation, leading to EITR reduction. The influence of fixed assets (STRAST) on EITR is positive. Similar results were obtained by Phillips (2003). It is possible that the CEO had bought assets for his own interest and so, the company registered higher non-deductible expenses that load EITR level. We checked the hypothesis $\mathrm{H}_{3}$. Financial leverage (LEV) recorded a negative correlation with effective tax rate. Similar results were obtained by Gupta and Newberry (1997) and the economic explanation is attributed to the fact that an increasing leveraging is a signal for a company which wants to expand its value by using debt (interest expenses means a lower EITR). We disproved the hypothesis $\mathrm{H}_{6}$. Indebtedness is a very powerful tool for a CEO because he can use it as a tax shelter and in the same time, he can invest the borrower's capital in more risky projects, but with a bigger return for company. For GROWTH variable we obtained a positive correlation with EITR, although we expected the effect of reducing the effective tax rate. We attributed this result to "political cost" which means that a growing company will be taxed for its success. We checked the hypothesis $\mathrm{H}_{8}$. Another reason may be the manager's difficulty to adapt to the continuous growth of the company.

For the CEO remuneration only SALARY and BONUS had a correlation with EITR. The variable SALARY recorded a negative correlation. A CEO must demonstrate his managerial skills to receive his salary and he can achieve this by maintaining a high financial performance, deriving from a quality financial management. Part of the financial management is fiscal management, which consists of tax optimization and thus, in reducing of EITR. The variable BONUS recorded a positive correlation. One possible explanation results from the idea of human nature. Bonuses are pecuniary incentives and can have adverse effects on tactics adopted by the CEO Manager. As a consequence of greed and other vices, he can use techniques or strategies characterized by excessive aggressiveness in the endeavor of EITR reduction, which can harm the company's financial performance. Wanting to get bonuses, the CEO may choose a high-debt policy, increasing the risk of bankruptcy and endangering the company. Ultimately, the chase of low effective tax rates can bring more costs which will end with a higher level for EITR.

\section{Conclusions}

Apart from corporate finance analyses of interest to shareholders, investors, state and public, a company can be analyzed using other interesting topics. Fiscal management and effective corporate tax rate (EITR) could indicate, in correlation with other indicators, the effectiveness of a company. With the elements of corporate governance and human nature incorporated in research study, the effective tax rates can indicate a lack of protection of minority shareholders.

Research on 50 companies from the United States of America has revealed some influential factors on EITR. The results are robust and they are obtained using numerous estimation methods (GLS, FE, White's correction); fact that supports the validity of the correlations. The results are also supported by the academic literature. Among them we identified a positive correlation between financial performance, ROA, and EITR which can be attributed to a lower activity or an inefficient management. Other correlations showed that the increased tax deductions and financial performance resulted from indebtedness (DEBT, LEV), will be reflected in a decrease of effective corporate tax rate, but a level to high of indebtedness can have an adverse effect on it. We registered an unexpected positive influence on EITR from the fix assets, capital intensity, probably due to non-deductible expenses. This correlation can be explained by the positive significance obtained for variable GROWTH, which can be linked to the concept of "political cost". This result is in contrast with firm size (SIZE) that had a negative correlation with EITR.

Very interesting results were obtained for variables which represent the CEO remuneration. Even if stock award did not record a statistical significance, the other two variables did. The correlation with effective 
corporate tax rate was mixed. SALARY recorded a negative correlation, an expected thing, knowing that, depending on the fiscal and financial results obtained, the manager is paid. For variable BONUS the positive correlation with EITR can be explained by the human nature, in the sense that a manager will act in his own interest, for obtaining the bonuses, and will lose focus on the global financial performance of the company. A bad financial performance followed by losses will increase the level of EITR. This is a very attractive topic and it opens new frontiers and new perspective for future research.

\section{References}

1. Al-Najjar, B. (2014). 'Corporate governance, tourism growth and firm performance: Evidence from publicly listed tourism firms in five Middle Eastern countries'. Tourism Management, 42, 342351.

http://dx.doi.org/10.1016/j.tourman.2013.0 9.008

2. Andrei, T and R. Bourbonnais, (2008)

'Econometrics', Ed.Economică, Bucharest

3. Bauman, C., and Schadewald, M. (2001) 'Impact of foreign operations on reported effective tax rates: interplay of foreign taxes, US taxes and US GAAP', Journal of International Accounting, Auditing \& Taxation, 10 , pp. 177-196

4. Brooks Chris (2008) 'Introductory Econometrics for Finance- second edition', Cambridge University Press, New York

5. Buijink, W., Janssen, B., and Scholes, Y. (2002), 'Evidence of the effect of domicile on corporate average effective tax rates in the European Union', Journal of International Accounting, Auditing and Taxation, 11, 115130.

6. Coles J., W., McWilliams, V. and Sen N., (2001) 'An examination of the relationship of governance mechanisms to performance', Journal of Management, Vol. 27, Feb, pg 23-50

7. Devereux, Michael P. and Rachel Griffith (1999),'The Taxation of Discrete Investment Choices', Revision, The Institute For Fiscal Studies Working Paper Series No. W98/16.
8. Djankov, S., Ganser, T., McLeish, C., Ramalho, R. and Shleifer, A., (2010) 'The Effect of Corporate Taxes on Investment and Entrepreneurship', American Economic Journal Macroeconomics

9. Gropp Reint, (1997) 'The Effect of Expected Effective Corporate Tax Rates on Incremental Financing Decisions '. IMF Working Paper, Vol., pp. 1-32

10.Gujarati, D. N. (2004). 'Basic Econometrics' (4th Edition). New York: Tata McGraw Hill.

11. Gupta, S. and Newberry, K., (1997) 'Determinants of the Variability in Corporate Effective Tax Rates: Evidence from Longitudinal Data', Journal of International Accounting and Public Policy, 16, pp.1-34

12. Haldane, A. G. (2011b) 'Control rights (and wrongs)' Retrieved from http://www.bankofengland.co.uk/publicatio ns/Documents/speeches/2011/speech525.p df

13. Hsieh Y.C. (2012), 'New evidence on determinants of corporate effective tax rates', African Journal of Business Management, Vol. 6(3), pag. $1170-1180$

14. Kern, B., and Morris, M. (1992). 'Taxes and firm size: The effects of tax legislation during the 1980s'. Journal of the American Taxation Association, 14(1), 80-96.

15.Lee N. and Swenson C., (2012) 'Are Multinational Corporate Tax Rules as Important as Tax Rates?', The International Journal of Accounting 47 (2012) 155-167

16. Md Noor, R., Fadzillah, N.S.M. and Mastuki, N., (2010) 'Corporate Tax Planning: A Study On Corporate Effective Tax Rates of Malaysian Listed Companies', International Journal of Trade, Economics and Finance, Vol. 1 , No. 2

17. Nicodème, G. (2007a) 'Comparing Effective Corporate Tax Rates, Frontiers in Finance and Economics', Volume 4, Issue 2, 102-131.

18. Nicodème, G. (2007b), 'Do Large Companies Have Lower Effective Corporate tax Rates? A European Survey', CEB Working Paper, 07/001 
19. Phillips, J.D., (2003) 'Corporate Tax-Planning Effectiveness: The Role of Compensation-Based Incentives'. The Accounting Review: July 2003, Vol. 78, No. 3, pp. 847-874.

20. Richardson, G. and Lanis, R., (2007) 'Determinants of the variability in corporate effective tax rates and tax reform: Evidence from Australia', Journal of Accounting and Public Policy, 26, 2007, pp. 689-704

21. Vintilă G., Cârstea F. and Dascălu L.A., (2012) 'The study on the factors influencing the effective tax rate' Colecţia de working papers ABC-ul LUMII FINANCIARE
22. Vintilă Georgeta and Păunescu Radu Alin, (2014) „Study on the effective corporate tax rate from the perspective of Griffith Devereux methodology", Working papers collection ABC-ul LUMII FINANCIARE, ASE ISSN -L 2344-1844

23. Zimmerman, J., (1983).'Taxes and firm size'. Journal of Accounting and Economics 5 (2), 119-149. http://taxfoundation.org/article/corporateincome-tax-rates-around-world-2015

24. Corporate Governance Policies, updated September 27, 2013, http://www.ecgi.org/codes/all_codes.php 